References

1. Naboka Y. L., Kogan M. I., Gudima I. A., Chernickaja M. L., Ibishev Kh. S. Role of non-clostridial anaerobes in the development of infectious and inflammatory diseases of the urinary and reproductive systems. Urology. 2013;4:16-18.

2. Kogan M. I., Naboka Y. L., Gudima I. A., Gazaev Z. I., Ibishev Kh. S. et al. New view on etiological structure of the acute obstructive pyelonephritis. Contemporary problems of science and formation. 2012;4. www. science-education.ru.

3. Apostolopoulou C., Konstantoulaki S., Androulakakis P. Vatopoulou T., Varkarakis M. Isolation of anaerobic organisms from kidney in serious renal infections. Urology. 1982;20(5):479-481.

4. Brook I. Urinary tract infection caused by anaerobic bacteria in children. Urology. 1980;16(6):596-598.

5. DuPrey K. M., McCrea L., Rabinowitch B. L., Azad K. N. Pyelonephritis and Bacteremia from Lactobacillus delbrueckii. Case Rep. Infect. Dis. 2012;10:1155-1158.

6. Giamarellos-Bourboulis E., Adamis T., Laoutaris G., Sabracos L., Koussoulas V. Immunomodulatory clarithromycin treatment of experimental sepsis and acute pyelonephritis caused by multidrug-resistant Pseudomonas aeruginosa. Antimicrobial Agents and Chemotherapy. 2004;48(1):93-99.

About authors:

Pasechnik Dmitry, MD, Head of Central scientific research laboratory; tel.: +792888428-41; e-mail: passetchnikdg@hotmail.com

Kogan Mikhail, MD, PhD, Professor, Head of Department of urology and human reproductive health with child urology

andrology course of the FPK and PPS; tel.: +79282260126; e-mail: dept_kogan@mail.ru

Naboka Yulia, MD, PhD, Professor of Department of microbiology and virusology № 1; tel.: +79289074013; e-mail: nagu22@mail.ru

Ibishev Khalid, MD, PhD, Professor, Head of Department of urology and human reproductive health with child urology

andrology course of the FPK and PPS; tel.: +79287777714; e-mail: ibishev22@mail.ru

Bejanyan Saro, postgraduate at Department of urology and human reproductive health with child urology

andrology course of the FPK and PPS; tel.: +79508444882; e-mail: sarik2802@yandex.ru

(C) Group of authors, 2016

UDC 616.716.8.002.69:352.41/16.32.09

DOI - http://dx.doi.org/10.14300/mnnc.2016.11039

ISSN - 2073-8137

\title{
PATHOMORPHOLOGICAL CHANGES OF DENTAL PULP IN EXPERIMENTAL OSTEOPOROSIS
}

Sirak S. V. ', Shchetinin E. V. ', Sirak A. G. ${ }^{1}$, Koshel I. V. ${ }^{1}$, Kobylkina T. L. ${ }^{1}$, Aybazov M. M. ${ }^{2}$, Vafiadi M. Yu. ${ }^{1}$, Adamchik A. A. ${ }^{3}$, Mamontova T. V. ${ }^{2}$

' Stavropol State Medical University, Russian Federation

${ }^{2}$ All-Russian Research Institute of Sheep and Goat Breeding, Stavropol, Russian Federation

${ }^{3}$ Kuban State Medical University, Krasnodar, Russian Federation

\section{ПАТОМОРФОАОГИЧЕСКИЕ ИЗМЕНЕНИЯ ПУАЬПЫ ЗУБОВ ПРИ ЭКСПЕРИМЕНТААЬНОМ ОСТЕОПОРОЗЕ}

\author{
С. В. Сирак', Е. В. Щетинин', А. Г. Сирак', И. В. Кошель', Т. А. Кобылкина', \\ М. М. Айбазов ${ }^{2}$ М. Ю. Вафиали', А. А. ААамчик ${ }^{3}$, Т. В. Мамонтова ${ }^{2}$
}

\footnotetext{
' Ставропольский госуаарственный меАицинский университет, Российская ФеАерация

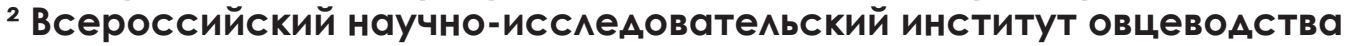
И козовоАСтва РАН, Ставрополь, РосСиЙская ФеАерация

${ }^{3}$ Кубанский госУАарственный МеАицинский Университет, КрасноАар, Российская ФеАерация
}

The study focused on pathomorphological changes taking place in the tooth pulp in sheep in case of experimental osteoporosis. The pulp was extracted after cracking the teeth. The sections were stained with hematoxylin and eosin by Masson, and impregnated with silver by Foot and Bielschowsky-Gros. There were severe vascular disturbances 
detected (vasodilation, stasis, perivascular edema with cell infiltration, hemorrhages), which resulted in vacuolization of odontoblasts, pulp reticular dystrophy, disintegration of argyrophilic and nerve structures. Such disturbances came along with proliferation of cell elements in the connective tissue and in nerve elements with denticle development.

Key words: osteoporosis, pulp, experiment, odontoblasts

Изучены патоморфологические изменения пульпы зубов овец при экспериментальном остеопорозе. Пульпу извлекали после раскалывания зубов. Срезы окрашивали гематоксилин-эозином, по Массону и импрегнировали серебром по Бильшовскому - Гросс и Футу. Установлены глубокие сосудистые нарушения (расширение сосудов, стаз, периваскулярный отек с клеточной инфильтрацией и кровоизлияниями), приводящие к вакуолизации одонтобластов, сетчатой дистрофии пульпы и к нарушению целостности аргирофильных и нервных структур. Эти нарушения сочетались с явлениями пролиферации клеточных элементов соединительной ткани и нервных элементов и с образованием дентиклей.

Ключевые слова: остеопороз, пульпа, эксперимент, одонтобласты

A number of authors suggest that a certain role in the pathogenesis of dental caries resides in the preceding organic and functional changes in the dental pulp, which are due to the influence of endogenous factors, such as endocrine disturbances accompanied by osteoporosis $[1,7$, 8]. There are also groups of drugs, prolonged use of which results in a decrease in bone density. This applies mainly to corticosteroids, anticonvulsants, immunosuppressants, and aluminum-containing preparations [2, 3]. In addition to bone deformities and pathological fractures due to lack of calcium in the oral cavity along with osteoporosis there appears the thinning of tooth enamel and increase of its sensitivity, loosening of teeth, and periodontal tissue destruction $[4,5,6]$. The development of pathogenetic methods for pulp pathology correction takes understanding of the mechanisms and pathomorphological changes in the pulp of intact teeth under osteoporosis, which was not to be found in the available literature.

Aim of this study was to investigate the state of the intact teeth pulp in sheep suffering from experimental osteoporosis.

Materials and Methods. This experimental study was conducted on 6 two-year sheep, North-Caucasian breed. Experimental osteoporosis model was created as follows. The animals underwent ovaryectomy, which was performed under general anesthesia (Zoletil 50). After that they were given intramuscular injections of dexamethasone $(10 \mathrm{mg} / \mathrm{kg}, 4$ injections per week) for 3 months. In all animals X-ray densitometry was carried out in 3 points located in the extremities, sacrum and in the mandibular body. The model was considered as formed when the deviations of the T-index from the normal values were in between 0 and -1 for normal bone density; -1 to -2.5 - osteopenia (bone loss); below -2.5 - osteoporosis.

30,60 and 120 days following the completion of the osteoporosis model, the lower incisors were removed under general anesthesia. The pulp was removed by the method of teeth cracking. The material was subjected to fixation for 8-10 days in $12 \%$ solution of neutral formalin to be further flushed with running water, dehydrated through alcohols of ascending density, and then embedded in celloidine. The slices $(3-5 \mu \mathrm{m})$ were stained with hematoxylin and eosin by Masson, impregnated with silver by Foot and Bielschowsky-Gros. The control animals were 6 intact sheep fed on regular diet.

The microscopy of the sections was performed on a digital microscope with a built-in camera Olympus BX45. 10 digital pictures were taken from each sample (format jpg; dimensions $-3136 \times 2352$ pixels in a $24 \mathrm{~b}$ graphic palette), under randomly selected vision fields, at $x 100$, $x 200, x 400$, and $x 1000$ magnification. The morphometric study was done using the software Video-Test Morphology 5.1 for Windows. The results obtained were analyzed employing the statistics method of Student's t-test in Primer of Biostatistics 4.03 for Windows. The statistically meaningful difference was taken at $p<0.05$.

The experiment involving animals was carried out subject to the principles of reasonable laboratory practice (National Standard PRINCIPLES OF REASONABLE LABORATORY PRACTICE GOST R 53434-2009) and an approval from the Ethical Committee, Stavropol State Medical University / StGMU, № 34, of February 12, 2014.

The research work was carried out as part of the Public Task from Ministry of Healthcare of Russian Federation for Stavropol State Medical University, within the area of Tooth Pulp Stem Cells in Regeneration \& Immune Modulation, together with the All-Russian Research Institute of Sheep and Goat Breeding and the Stavropol State Agrarian University (Stavropol, Russia).

Results. The animals revealed a general response to the ovaryectomy on Day 7 into the experiment, which manifested as increased appetite and activity. For two weeks the phenomena were growing, after which the activity gave way to retardation.

A histological study into the tooth pulp showed that 30 days into the experiment there were a set of changes that affected all the layers. The odontoblastic layer thickened with its cells showing some dystrophic changes - disorderly position, edema and sharply defined cytoplasmic basophilia. The odontoblasts' nuclei took some round or oval shape, acquired intensive coloring and were located in the basal or in the peripheral parts of the cell. Oftentimes the cytoplasm in the mentioned cells was vacuolated with the nuclei affected by pycnosis.

The other pulp layers revealed serious disturbances as well - tissue edema and softness while cell elements were mostly concentrated in groups. There were numerous round cell infiltrations detected around the vessels and nearby. At the same time there was proliferation of younger elements in the connective tissue like fibroblasts and histiocytes. The peripheral area of the pulp had low-organized denticles. Pulp hyperemia was notable. The vessels were dilated and congested with blood; prominent was swelling, separation of fibers, and protein impregnation of capillary vessel walls along with swelling and endothelium desquamation in the lumen. Staining by Foot showed uneven impregnation of argyrophilic fibers. Argyrophilic vascular membranes in some areas get deprived of their capacity for impregnation and appear like blurred stripes (Fig. 1a). Nerve fibers reveal elevated twist, hyperimpregnation, uneven thickening and phialine swelling of axis cylinders (Fig. 1b). 

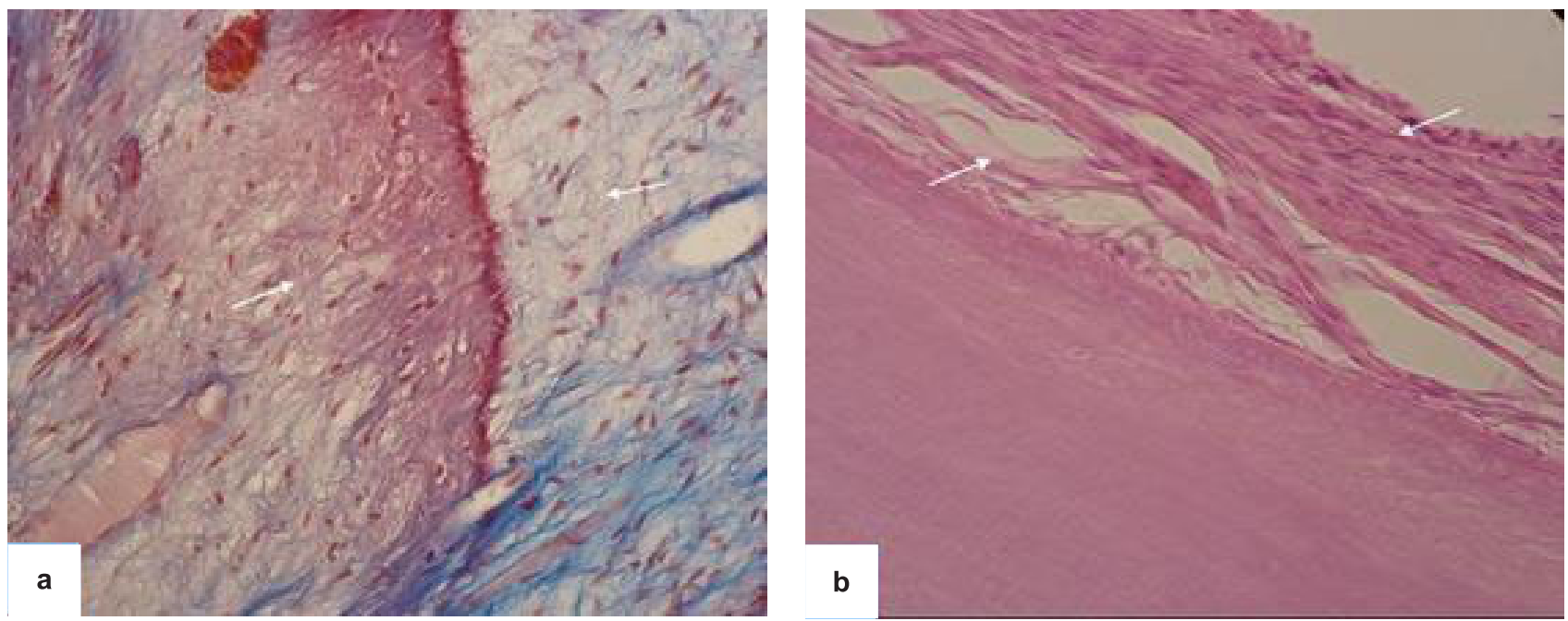

Fig. 1. Microslides of the major group on Day 30 of the experiment: a - uneven impregnation of argyrophilic fibers and vascular membranes of the tooth pulp (indicated with arrows). Staining by Foot. Oc. 15, obj. 40; b - bundle of tooth pulp nerve fibers, increased twist, hyperimpregnation and bulges (indicated with arrows). Impregnation of nerve fibers with silver by Bielschowsky - Gros. Oc. 15, obj. 40

60 days into the experiment, the said changes in the pulp increased. Odontoblasts become protruded and turn into thin intensively staining threads that are often subject to destruction. As part of the odontoblasts die there appear strictly outlined cavities of roundish or some irregular shape, due to which the peripheral areas of the pulp adopt some reticulate looks (Fig. 2a).
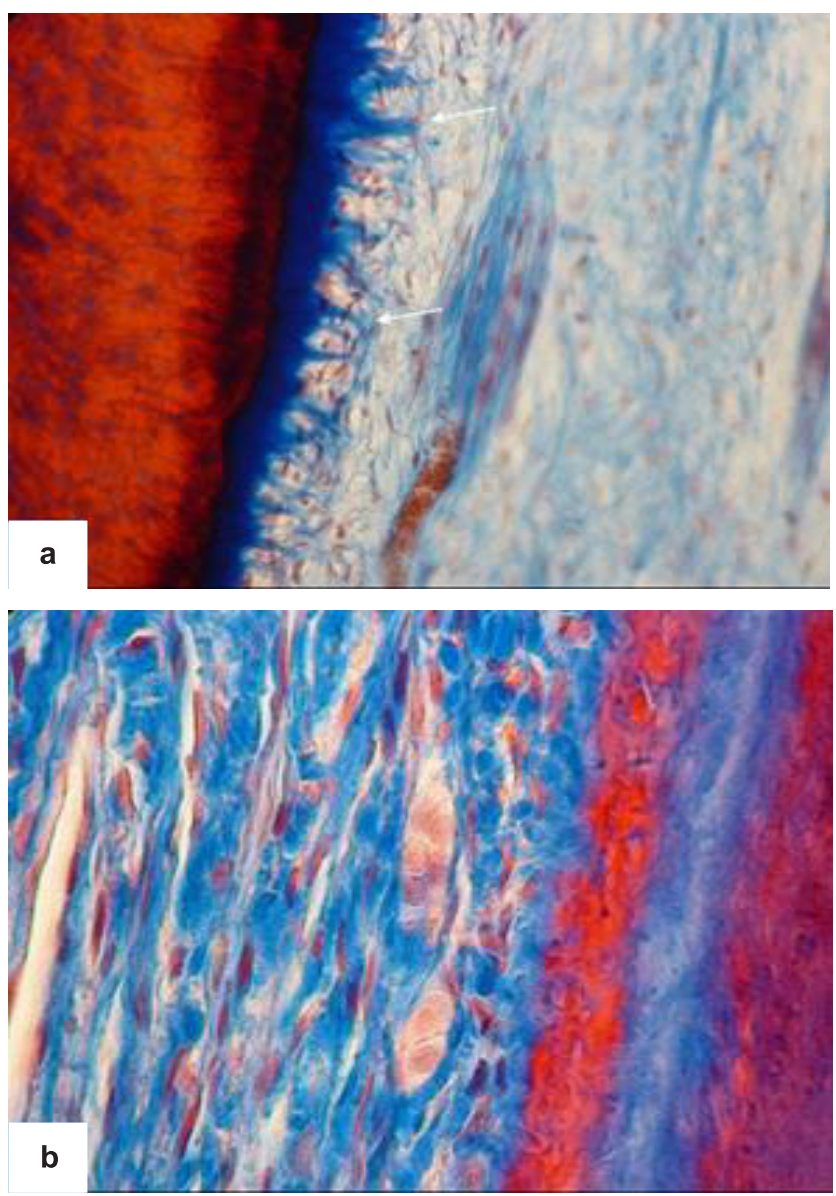

The connective tissue reveals fiber separation and is permeated with plasma proteins (Fig. 2b). There are perivascular calcifications to be seen rather often. Besides, roundish or uneven denticles can be observed, which get stained in the central pulp most intensively; adjacent to the denticles lie odontoblast-like cells with oval nuclei (Fig. 2c).
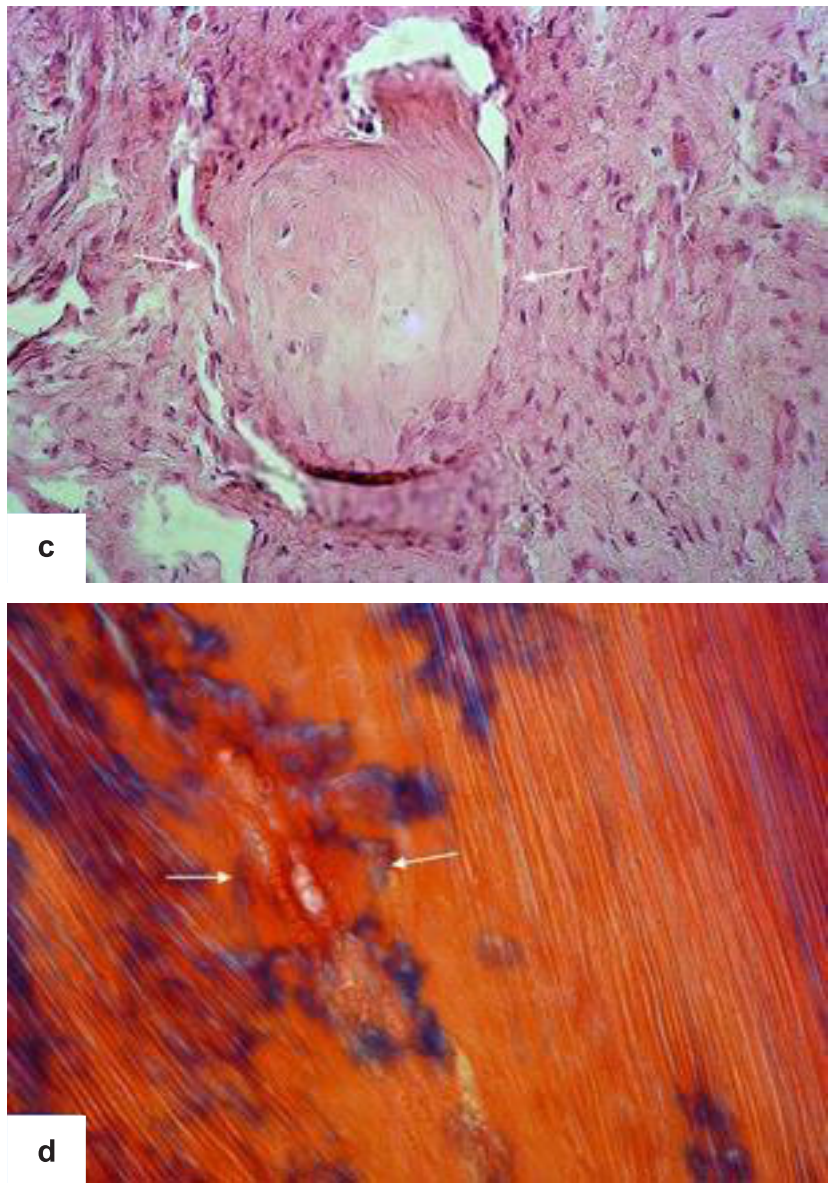

Fig. 2. Microslides of the major group on Day 60 of the experiment: a - vacuolization of odontoblasts. Staining by Masson. Oc. 20 , obj. 100; b - fiber separation and pulp permeation with protein. Staining by Masson. Oc. 20, obj. 100; c - parietal denticle in the tooth pulp (indicated with arrows). Hematoxylin \& eosin staining. Oc. 15, obj. 40; $d$ - changes in the artery wall (indicated with arrows) and lympho-histiocyte infiltration in the tooth pulp. Staining by Masson. Oc. 10, obj. 40 
Along with the changes above-mentioned, the pulp often revealed reticular dystrophy - in some areas the pulp was represented as a combination of thin and thick rough-fibered bars shaped in a net where the loops were of varying size and shapes. The central part of the pulp, in the meantime, manifested some dystrophic changes increased pulp hyperemia; destructive vasculitis appears noticeable; the foreground represents blood congestion, increased vessel wall premeability, perivascular edema, plasmorrhagia, diapedetic and focal hemorrhages. All the layers of the pulp revealed numerous extravasates, located both individually and in groups. Artery walls thickened due to swelling and hyperplasia of muscleelastic elements. Intensive and prominent was hyperchromatism in muscle cell nuclei and epithelium, while there was also present a phenomenon like focal and diffuse lympho-histiocyte infiltration (Fig. 2d).

There was increasing swelling and fiber separation noted in the intercellular substance, and blanching and melting argyrophylic frame. Deeper destructive changes were to be observed in the nerve elements along with hyperimpregnation areas there was loss in the argyrophylic capacity and total resorption of fibers. During that, the nerve elements lose their tinctorial features and appear as outlines alone. However, apart from regressive processes, the pulp also showed some proliferation of

\section{References}

1. Goldberg M., Farges J.-C., Lacerda-Pinheiro S. Inflammatory and immunological aspects of dental pulp repair. Pharmacological Research. 2008:58(2):137-147. doi: 10.1016/j.phrs.2008.05.013

2. Kanis J. A., McCloskey E. V., Johansson H. European guidance for the diagnosis and management of osteoporosis in postmenopausal women. Osteoporosis International. 2013;24(1):23-57. doi: 10.1007/s00198012-2074-y

3. Manolagas S. C., Jilka R L. Mechanisms of disease: Bone marrow, cytokines, and bone remodeling - Emerging insights into the pathophysiology of osteoporosis. New England Journal of Medicine. 1995;332(5):305311. doi: 10.1056/NEJM199502023320506

4. Ohshima H. Oral biosciences: The annual review 2015. Journal of Oral Biosciences. 2016;58(1):1-9. doi: 10.1016/j.job.2015.12.00 nerve elements - there were thin nerve fibrillas observed, which branched from thicker nerve stems.

120 days into the development of the osteoporosis model, the destructive changes in all the pulp layers were very prominent. The odontoblastic layer was mostly subject to vacuolization of both separate cells and the entire layer of odontoblasts. The pulp vessels tone was disturbed, too; there appeared phenomena like vessel bulge or, on the contrary - their luminal narrowing. Present also were significant roughening, hyperimpregnation, thickening of argyrophylic fibers, and their collagenization in some areas. The phenomena in question came along with intensification of the destructive changes in the nerve elements whereas many of these decomposed into lumps and grains, while their productive changes (nerve fibers regeneration) were poorly pronounced.

Conclusions. Experimental osteoporosis in tooth pulp comes along with deeper vascular disturbances (vasodilation, stasis, perivascular edema with cell infiltration, hemorrhages) resulting in odontoblastic dystrophy, reticular atrophy and pulp petrification, as well as in decomposition of argyrophilic and nerve structures. Along with that, there was proliferation of cell elements in the connective tissue observed, as well as denticles development. The outcomes obtained may allow planning pathogenetic methods for correcting pulp pathologies in case of osteoporosis.
5. Shchetinin E. V., Sirak S. V., Khodzhayan A. B. Pathogenetic aspects of dental pulp pathology. Medical News of North Caucasus. 2015;10(2):187-191. doi: 10.14300/ mnnc.2015.10044

6. Sirak A. G., Sirak S. V. Morfofunkcionalnie izmeneniya $\checkmark$ pulpe zubov eksperimentalnich zhivotnich pri lechenii glubokogo kariesa. Sovremennie problemi nauki i obrazovaniya. - Modern problems of science and education. 2013;2:44

7. Sirak S. V., Bykov I. M., Sirak A. G., Akopova L. V. Profilaktika kariesa i vospalitelnich zabolevaniy parodonta $\mathrm{s}$ ispolzovaniem zubnich eliksirov. Kubanskiy nauchniy medicinskiy vestnik - Kuban scientific medical bulletin. 2013;6:166-169.

8. Tella S. H., Gallagher J. C. Prevention and treatment of postmenopausal osteoporosis. Journal of Steroid Biochemistry and Molecular Biology. 2014;142:155-170. doi: 10.1016/j.jsbmb.2013.09.008

\footnotetext{
About authors:

Sirak Sergey, MD, PhD, Professor, Head of Department for Dentistry; tel.: +7(8652)350551; e-mail: sergejsirak@yandex.ru

Shchetinin Evgeny, MD, PhD, Head of Department for Pathological Physiology; tel.: +7(8652)352684; e-mail: ev.cliph@rambler.ru

Sirak Alla, MD, PhD, Head of Department for Hystology; tel.: +7(8652)350551; e-mail: sergejsirak@yandex.ru

Koshel Ivan, MD, cms, Associate Professor, Department of Othorhinolaryngology; tel.: +7(8652)350551; e-mail: koshel1979@mail.ru

Aybazov Magomet, MD, PhD, Professor, Head of Department for Sheep Breeding; tel.: $+7(8652) 717033$
} 